Agrotrópica 33(2): 91 - 100. 2021.

Centro de Pesquisas do Cacau, Ilhéus, Bahia, Brasil

\title{
NEW SOURCES OF RESISTANCE - CACAO GERMPLASM EVALUATION FOR NATURAL INCIDENCE OF WITCHES' BROOM
}

\author{
José Luis Pires*, Edna Dora Martins Newman Luz, Gilson Roberto Pires Melo \\ Comissão Executiva do Plano da Lavoura Cacaueira, Centro de Pesquisa do Cacau, Ilhéus, Bahia, Brazil. \\ joseluiszoegapires@gmail.com, ednadora@yahoo.com.br,grpmelo@uol.com.br, \\ *Corresponding author: joseluiszoegapires@gmail.com
}

\begin{abstract}
This study is part of the first ones that came to guide the recurrent selection processes for the association of resistance genes conducted by the Cocoa Research Center, at Ilhéus, Bahia. Two sets of accessions of the Cocoa Germoplasm Collection of this Center were evaluated for natural incidence of witches' broom, the biggest phytosanitary problem for cacao cultivation in Brazil. For the first set, which consisted of 573 accessions, it was considered the incidence of brooms on pods of up to 10 plants per row, with one or two rows of each accession, in five years of evaluation. For the second, formed by 154 genotypes pre-selected among the accessions introduced in the period with indications of good performance in relation to witches' broom, it was computed seven removals of vegetative brooms in the canopy, being each accession represented by one to three rows with up to seven plants. For both sets, a large number of genotypes of different origins were observed among the resistant ones, indicating the perspective of the occurrence of different resistance genes and possibilities of genetic gain in associating these different genes.
\end{abstract}

Key words: Moniliophthora perniciosa, plant breeding, Theobroma cacao.

Novas fontes de resistência - avaliação de germoplasma do cacaueiro para
ncidência natural da vassoura de bruxa. Este trabalho é parte dos primeiros estudos que vieram nortear os processos de seleção recorrentes para associação de genes de resistência conduzidos pelo Centro de Pesquisas do Cacau, em Ilhéus, Bahia. Dois conjuntos de acessos da Coleção de Germoplasma deste Centro foram avaliados quanto à incidência natural de vassoura de bruxa, o maior problema fitossanitário da cacauicultura no Brasil. Para o primeiro conjunto, com 573 acessos, foi considerada a incidência de vassouras em frutos de até 10 plantas por fileira, com uma ou duas fileiras por cada acesso, em cinco anos de avaliação. Para o segundo, formado por 154 genótipos pré-selecionados entre os acessos introduzidos no período com perspectivas de bom desempenho em relação à vassoura de bruxa, foram computadas sete remoções de vassouras vegetativas na copa, sendo cada acesso representado por de uma a três fileiras, com até sete plantas cada. Para ambos os conjuntos, foi observado um grande número de genótipos de diferentes origens entre os resistentes, indicando a perspectiva de ocorrência de diferentes genes de resistência e possibilidades de ganho genético na associação desses diferentes genes.

Palavras-chave: Moniliophthora perniciosa, melhoramento de plantas, Theobroma cacao. 


\section{Introduction}

Since the last decade of the 20th Century witches' broom disease (WBD) has threatened the cacao growing region of Southern Bahia State, Brazil, and the Brazilian cacao production was strongly reduced (Luz, Sgrillo and Santos Filho, 2005; Oliveira and Luz, 2012). Efforts have been applied to improve the cacao production and minimize losses through persistent replacement of susceptible Comum varieties by genetic materials carrying genes of resistance to Moniliophthora perniciosa (Singer) Aime \& PhyllipsMora, causal agent of WBD.

The central issue for the genetic improvement of cacao crop in Bahia became, then, the pursuit of resistant varieties. Populations were developed by crossing possible sources of resistance to WBD from different origins, including wild materials, and high yielded genotypes, to screening parents with high combining ability and selecting the most resistant and productive progenies, plants and clones, within a process of recurrent selection (Lopes et al., 2011; Pires et al., 2012a; Pires et al., 2012b). Results from this research were previously published (Albuquerque et al., 2010; Benjamin et al., 2016; Gramacho et al., 2016; Paim et al., 2006; Pimenta Neto et al., 2018; Rodrigues et al., 2020; Silva et al., 2010).

Efforts to reach improved genetic materials start by identifying genotypes carrying genes for WBD resistance through germplasm evaluation, a continuous and important step in any breeding program. This paper aims to reveal these early studies resulting in advances for the cacao breeding program for WBD resistance in Bahia, Brazil. And the hypothesis of the study is that there are resistant genotypes of different origins, what indicates perspectives of the occurrence of different resistance genes and possibilities of genetic gain in associating these different genes.

\section{Materials and Methods}

Two sets of accessions were evaluated, the first consisting of 573 accessions, planted between 1978 and 1990, and the second with 154 clones, established in the field by grafting onto adult plants in the years 1998 and 1999. For the first set, it was considered the incidence of brooms on pods of up to 10 plants per row, one or two rows as representatives of each accession, and 5 years of evaluation (1995 to 1999 12 harvests). For the second, it was computed 7 removals of vegetative brooms in the canopy, from 1999 to 2002 , with each clone represented by one to three rows with up to 7 plants.

Set 1 - distinctions among accession groups for pod infection by Moniliophthora perniciosa, correlations between this characteristic, other symptoms and black pod disease incidence (Phytophthora spp.)

The variable produced by the ratio between the number of WBD infected pods (sum of all pods in the row, per harvest) and the sum of healthy and infected pods, was considered. Analyzes were carried out with the following sources of variation: harvest, group of accessions, accession within group and the interactions harvest $\mathrm{x}$ group of accessions and harvest $\mathrm{x}$ accession within group. To estimate adjusted means and contrasts among means, the model was reduced by removing the interactions (SAS INSTITUTE, 1988).

The correlations between the WBD infected pods and the number of vegetative brooms, cushion brooms and the black pod rot (BPR) infected pods were also analyzed, using data from Pires, Luz and Lopes (1997) and others from more recent cacao germplasm evaluations.

Set 2 - distinctions among accessions and accession groups for vegetative brooms

The Set 2 was established in two areas, one with 91 (subset A) and another with 63 accessions (subset B), and these were analyzed separately.

The subset A was divided into two blocks of proportional dimension areas, the first comprising accessions planted in 1998 and accessions planted in 1999, and the second only accessions planted in 1999. Of these 91 accessions, 33 are represented by two or three rows and the rest for just one.

For this subset A, analyzes of the differences among accessions were performed according to the model with the following sources of variation: removal period, block, planting age, accession, removal period $\mathrm{x}$ accession, planting age $\mathrm{x}$ accession and trunk area 20 $\mathrm{cm}$ above the ground (covariate for covariance analysis, obtained by converting the diameter of the 
trunk or main branches of the plant, considered as circular, into area); and accessions averages were estimated by removing interactions from the model. In turn, the analysis of differences among groups or series of accessions of common origin followed the model: removal period, block, planting age, group, accession within group, removal period $\mathrm{x}$ group, planting age $\mathrm{x}$ group, removal period $\mathrm{x}$ accession within group, planting age $\mathrm{x}$ accession within group and trunk area $20 \mathrm{~cm}$ (covariate - covariance analysis); and groups averages were also estimated by removing interactions from the model (SAS INSTITUTE, 1988).

For subset B, which includes only accessions represented by a single row, the analyzes of the differences among accessions were carried out, initially, having as sources of variation: removal period, accession, removal period $\mathrm{x}$ accession and trunk area at $20 \mathrm{~cm}$ from the ground (covariable); and the difference among groups: removal period, group, accession within group, removal period x group, removal period $x$ accession within group and trunk area. In the interpretation of the differences among accessions, to reduce the tendency of errors resulting from the influence of the fixed effects of the environment in these differences, the residue was increased by the disregard of the removal period $\mathrm{x}$ access interaction. The groups and accessions averages were again estimated by removing the interactions from the models, and in these, as in the previous ones, all effects, with the exception of block effect, were considered fixed.

\section{Results and Discussion}

\section{1-Accessions set 1 - distinctions among accession groups regarding infection in pods}

\section{1 - Data quality}

In Set 1, a group of 23 accessions, represented in the collection by more than one row, presented for the variable percentage of infected pods $(\mathrm{IP} \%=100$ times the ratio: number of WBD infected pods over the number of WBD infected pods plus the number of healthy pods) a coefficient of variation of $19.47 \%$ for the averages of rows within accession, obtained from the model with the sources of variation: harvest period $(\mathrm{Hp})$, accession (A) and row (R) within accession.
With this model, significant effects of $\mathrm{Hp}$ (at $0.01 \%$ ), significant differences among A (at $0.01 \%$ ) and nonsignificant for row within accession effects (44.27\%) were observed, which could suggest that the fixed effects of environment are not important (only the Hp with medium levels of infection, which allow a better differentiation of genotypes, as will be seen late, were considered). This observation, however, contrasts with what indicate the high coefficient of variation average. It also opposes to the values observed for the correlations among row within accessions averages and the coefficients of determination for the repeatability of these averages. The correlation and the coefficients of determination, for the methods of Analysis of Variance, Main Component and Structural Analysis (Cruz, 1997; Cruz, Carneiro and Regazzi, 2014), were, respectively, 0.86 and from 92.15 to 92.40 , for the situation in which the highest averages of the various genotypes are grouped in one set and the lowest in another, and 0.54 and from 69.22 to 71.89 , for the situation in which half of the highest averages among the pairs of averages of accessions and half of the lowest formed each set used for the calculation.

The coefficients of determination for a single row, considering the two situations described, are slightly less than $85 \%$ for the first situation, and well below $70 \%$ for the second.

Thus, considering these values, the option was to restrict the analysis of the incidence of WBD in pods to the differences among series or groups of genotypes of related origin, without any considerations on the individual accession performance. The genotype groups considered have a distribution in the collection close to a random distribution.

\section{2 - Distinctions among accession groups}

The groups or series of genotypes were listed, or formed, according to their origin (Wadsworth et al., 1997), with the elements of distinct formation in relation to their series having been separated (Table 1).

During the period considered, the germplasm collection had averages of infected pods (IP\%) among 13.66 and $87.37 \%$ : $13.96 ; 87.37 ; 69.69 ; 13.66 ; 60.40$; $45.23 ; 22.05 ; 29.04 ; 35.64 ; 80.40 ; 55.41$; and $51.00 \%$. The average number of pods considered per clone/ harvest was 32 and cases with less than 4 pods in one harvest were not considered. 
Table 1 - List of studied groups

\begin{tabular}{|c|c|c|}
\hline Origin & Group/Series & Description \\
\hline State of Acre & $\mathrm{AC}$ & series $\mathrm{CAB}, \mathrm{AB}, \mathrm{IQ}, \mathrm{SE}$. \\
\hline State of Amazonas & $\mathrm{AM}$ & series $\mathrm{CAB}, \mathrm{AM}$. \\
\hline State of Bahia & BAH & $\begin{array}{l}\text { selections in varieties from Bahia, } \\
\text { E. Santo - series Cepec }\end{array}$ \\
\hline State of Pará & $\mathrm{BE}$ & series $\mathrm{Be}$ \\
\hline State of Amazonas & $\mathrm{CA}$ & series $\mathrm{Ca}$ \\
\hline State of Pará, Exp. station & CAS & series CAS \\
\hline Costa Rica & $\mathrm{CC}$ & series CC \\
\hline \multirow[t]{2}{*}{ Equador } & $\mathrm{CCN}$ & series $\mathrm{CCN}$ \\
\hline & CEQ & series Cepec - family of unknown origin \\
\hline State of Bahia - hybrids & $\mathrm{CHC}$ & series Cepec - Criollo hybrids \\
\hline State of Amapá & CJ & series CJ \\
\hline State of Acre & $\mathrm{CSU}$ & series Cruzeiro do Sul \\
\hline State of Bahia - hybrids & $\mathrm{CTF}$ & series Cepec - Trinitario x Forastero hybrids \\
\hline State of Espirito Santo & EEG & series EEG \\
\hline Equador & EET & series EET \\
\hline Granada & GS & series GS \\
\hline Trinidade & ICS & series ICS \\
\hline Peru-Amazon & IMC & series IMC \\
\hline State of Amazonas & MA & series Ma \\
\hline México & MEX & series $\mathrm{P}$ \\
\hline Equador & MOQ & series Moq \\
\hline Peru-Amazon & NA & series $\mathrm{Na}$ \\
\hline Venezuela & $\mathrm{OC}$ & series Oc \\
\hline Peru-Amazon & PA & series $\mathrm{Pa}$ \\
\hline State of Pará & PAR & series $\mathrm{CAB}$ \\
\hline Peru-Amazon & PER & genotypes from Peru - series: Amazon, Mo \\
\hline Peru-Amazon & POU & series Pound \\
\hline State of Acre & $\mathrm{RB}$ & series RB \\
\hline México & RIM & series RIM \\
\hline State of Roraima & RR & series $\mathrm{CAB}$ \\
\hline Colômbia & $\mathrm{SC}$ & series SC \\
\hline Peru-Amazon & SCA & series Scavina \\
\hline Equador e Trinidade & SD1 & Scavina 6 descendants - series: TSA, TSH, EET \\
\hline State of Bahia & $\mathrm{SD} 2$ & Scavina 6 descendants - series Cepec \\
\hline Guatemala & SGU & series Sgu \\
\hline State of Bahia & SAI & series SIAL \\
\hline State of Bahia & SIC & series SIAL \\
\hline Colômbia & SPA & series SPA \\
\hline Colômbia & SPE & series SPEC \\
\hline Costa Rica & UF & series UF \\
\hline
\end{tabular}

The IP\% variable had a different distribution from the normal by the KolmogorovSmirnov test (SAS INSTITUTE, 1988), with strong deviations, mainly, for the high and low infection levels $(\mathrm{D}=0.188 ; 0.061$ and 0.227 ; for the low, medium and high level, respectively), and among several transformations tested, the one that produced the best effects was the arcsin of the square root of the proportion between the number of WBD infected pods and the sum of the numbers of healthy and infected pods $(\mathrm{D}=0.160 ; 0.071$ and $0.163)$. This transformation was used for data analysis. It produced a small increase in deviation to the medium level, but it was also applied to this level to maintain a standard.

In the analyzes, the limit of seven times for the ratio between the highest and lowest variance within the groups was respected, so that, for the high level, it was necessary to exclude the series $\mathrm{CCN}, \mathrm{APA}, \mathrm{CJ}$ and EEG, for the medium the series APA, and for the low level the groups AM and RR (Table 2).

Harvest period and groups, or series of genotypes, were distinguished by $0.01 \%$ at high, medium and low levels, and the effects of clone within series were identified as significant at $0.01 \%$ at medium and high levels, and as not significant at low, for
In order to focus on an element strongly questioned by farmers who cultivate resistant varieties descended from Scavina, which is the high pod losses in some situations, the analyzes were conducted separately for three levels of infection: high, medium and low, limited by arbitrary values of $65 \%$ and $25 \%$ of loss in average.
$10 \%$ probability of error. The harvest period $\mathrm{x}$ group interaction was significant at $0.01 \%$ at medium and high levels and at $\%$ at low level; and the interaction harvest period $\mathrm{x}$ clone within the group was only significant at the high level $(0.02 \%)$, and not in the others, at $10 \%$. 
Table 2 - Group means for the WBD infected pods: transformed (IPtr) and untransformed variable (IP\%), probability of error for the rejection of the contrast null hypothesis for each group and the Scavina series, by the T test, at the levels of low (L), medium (M) and high inoculum pressure (H) (Prob), and Least Significant Difference for Tukey, at $5 \%$, for group (LSD)

\begin{tabular}{|c|c|c|c|c|c|c|c|c|c|}
\hline \multirow{2}{*}{ Group } & \multicolumn{3}{|c|}{ M } & \multicolumn{3}{|c|}{ H } & \multicolumn{3}{|c|}{ L } \\
\hline & IPtr & Prob & IP\% & IPtr & Prob & IP\% & IPtr & Prob & IP\% \\
\hline $\mathrm{AC}$ & 0.564 & 0.0699 & 31.46 & 1.234 & 0.0593 & 82.46 & 0.221 & 0.1008 & 10.55 \\
\hline APA & & & & & & & 0.813 & $<.0001$ & 55.92 \\
\hline $\mathrm{AM}$ & 0.677 & 0.0057 & 42.65 & 1.160 & 0.2000 & 79.43 & & & \\
\hline $\mathrm{BAH}$ & 0.852 & $<.0001$ & 54.07 & 1.222 & 0.0422 & 82.20 & 0.327 & 0.0110 & 17.95 \\
\hline $\mathrm{BE}$ & 0.762 & $<.0001$ & 48.32 & 1.151 & 0.1304 & 79.13 & 0.305 & 0.0137 & 13.84 \\
\hline $\mathrm{CA}$ & 0.897 & $<.0001$ & 57.72 & 1.214 & 0.0480 & 83.25 & 0.426 & 0.0011 & 21.61 \\
\hline CAS & 0.726 & 0.0011 & 43.93 & 1.303 & 0.0151 & 89.23 & 0.296 & 0.0301 & 12.86 \\
\hline $\mathrm{CC}$ & 0.861 & $<.0001$ & 55.31 & 1.316 & 0.0042 & 87.58 & 0.397 & 0.0017 & 24.12 \\
\hline $\mathrm{CCN}$ & 0.922 & $<.0001$ & 60.72 & & & & 0.354 & 0.0094 & 19.21 \\
\hline CEQ & 0.601 & 0.0230 & 35.95 & 0.286 & $<.0001$ & 14.38 & 0.060 & 0.5061 & 1.34 \\
\hline $\mathrm{CHC}$ & 0.770 & $<.0001$ & 48.64 & 1.126 & 0.1897 & 76.07 & 0.350 & 0.0051 & 17.50 \\
\hline $\mathrm{CJ}$ & 0.810 & $<.0001$ & 51.49 & & & & 0.363 & 0.0052 & 17.36 \\
\hline $\mathrm{CSU}$ & 0.651 & 0.0049 & 37.71 & 1.108 & 0.2487 & 71.17 & 0.210 & 0.0769 & 10.33 \\
\hline $\mathrm{CTF}$ & 0.781 & $<.0001$ & 49.21 & 1.116 & 0.2159 & 77.03 & 0.268 & 0.0261 & 11.97 \\
\hline EEG & 0.830 & $<.0001$ & 53.64 & & & & 0.292 & 0.0171 & 13.76 \\
\hline EET & 0.682 & 0.0020 & 41.20 & 1.159 & 0.1147 & 80.56 & 0.382 & 0.0035 & 18.21 \\
\hline GS & 0.796 & 0.0001 & 49.85 & 1.075 & 0.4349 & 72.07 & 0.291 & 0.0342 & 13.06 \\
\hline ICS & 0.801 & $<.0001$ & 50.04 & 1.192 & 0.0520 & 78.97 & 0.509 & $<.0001$ & 30.88 \\
\hline IMC & 0.656 & 0.0037 & 39.69 & 1.112 & 0.2352 & 75.60 & 0.198 & 0.0924 & 8.44 \\
\hline MA & 0.734 & 0.0004 & 46.85 & 1.317 & 0.0084 & 89.17 & 0.339 & 0.0097 & 14.88 \\
\hline MEX & 0.933 & $<.0001$ & 63.09 & 1.320 & 0.0059 & 91.11 & 0.341 & 0.0116 & 17.34 \\
\hline MOQ & 0.781 & 0.0004 & 47.89 & 1.157 & 0.2110 & 81.55 & 0.314 & 0.0325 & 18.08 \\
\hline NA & 0.709 & 0.0012 & 42.13 & 1.191 & 0.1138 & 78.05 & 0.367 & 0.0086 & 18.25 \\
\hline $\mathrm{OC}$ & 0.642 & 0.0111 & 39.39 & 1.139 & 0.2104 & 75.82 & 0.365 & 0.0076 & 16.85 \\
\hline PA & 0.571 & 0.0303 & 32.33 & 1.031 & 0.5611 & 71.26 & 0.216 & 0.0594 & 8.93 \\
\hline PAR & 0.723 & 0.0006 & 46.32 & 1.265 & 0.0207 & 83.88 & 0.188 & 0.1265 & 7.57 \\
\hline PER & 0.686 & 0.0024 & 42.36 & 1.067 & 0.4531 & 75.17 & 0.311 & 0.0161 & 16.11 \\
\hline POU & 0.617 & 0.0108 & 36.38 & 1.147 & 0.1419 & 75.40 & 0.349 & 0.0053 & 16.61 \\
\hline $\mathrm{RB}$ & 0.638 & 0.0053 & 38.95 & 1.172 & 0.0854 & 77.65 & 0.297 & 0.0145 & 17.48 \\
\hline RIM & 0.967 & $<.0001$ & 64.36 & 1.335 & 0.0013 & 90.59 & 0.486 & 0.0001 & 27.91 \\
\hline RR & 0.635 & 0.0305 & 37.26 & 1.233 & 0.1319 & 84.19 & & & \\
\hline $\mathrm{SC}$ & 0.770 & 0.0002 & 49.95 & 1.328 & 0.0068 & 89.67 & 0.339 & 0.0107 & 17.47 \\
\hline SCA & 0.361 & & 23.99 & 0.965 & & 62.58 & -0.004 & & -2.09 \\
\hline SD1 & 0.533 & 0.0845 & 29.34 & 1.028 & 0.5898 & 69.35 & 0.204 & 0.0797 & 7.22 \\
\hline SD2 & 0.680 & 0.0011 & 41.09 & 1.076 & 0.3380 & 72.23 & 0.266 & 0.0242 & 11.43 \\
\hline SGU & 0.783 & $<.0001$ & 48.60 & 1.168 & 0.1312 & 78.69 & 0.319 & 0.0149 & 14.66 \\
\hline SIA & 0.769 & $<.0001$ & 47.97 & 1.232 & 0.0180 & 83.50 & 0.255 & 0.0274 & 11.11 \\
\hline SIC & 0.910 & $<.0001$ & 59.89 & 1.334 & 0.0011 & 88.80 & 0.438 & 0.0004 & 23.74 \\
\hline SPA & 0.746 & 0.0002 & 47.71 & 1.267 & 0.0190 & 83.95 & 0.234 & 0.0563 & 12.61 \\
\hline SPE & 0.702 & 0.0041 & 44.60 & 1.278 & 0.0488 & 86.72 & 0.299 & 0.0302 & 13.85 \\
\hline UF & 0.887 & $<.0001$ & 57.11 & 1.174 & 0.0712 & 78.67 & 0.417 & 0.0010 & 24.74 \\
\hline $\mathrm{VE}$ & 0.690 & 0.0029 & 41.44 & 1.221 & 0.0596 & 82.06 & 0.260 & 0.0552 & 11.38 \\
\hline LSD & 0.239 & & & 0.258 & & & 0.327 & & \\
\hline
\end{tabular}

For the medium level of infection, or inoculum pressure, the Scavina series (Clones Scavina 6 and Scavina 12 - the most traditional sources of resistance to WBD) has a clear superiority over the local varieties (SIC, SIAL, EEG and BAH), and only does not differ, at $5 \%$, from the group of their descendants SD1 and from the group $\mathrm{AC}$, from Acre (Table 2 - contrasts).

With the high level, the Scavina series is still distinguished from the local groups SIC, SIAL and BAH, but the differences are proportionally smaller, and this series does not differ significantly, at $5 \%$, from 23 of the evaluated groups (also due to a smaller number of evaluated harvests). The average for SD1, which represents great part of the varieties indicated for commercial planting, also approximates the averages of local varieties, so that, for these varieties, a great number of infected pods is expected in commercial planting with high inoculum pressure.

The CEQ group significantly outperforms the Scavinas, but this result is, most certainly, due to scape, and its average for the high level of inoculum pressure is lower than that observed for the medium level. 
It can be noted, by the general harvest averages, that periods with large losses for Scavinas and descendants precede others of medium and low losses, so that there was no reason, at this time, to suppose the occurrence of changes in the pathogen towards the expansion of its virulence over resistant genotypes, an element that was verified posteriorly (Pires et al., 2012a, Pires et al., 2012b).

For the low level, the Scavina series shows again the lowest average and is distinguished from local varieties. However, due to the lower precision in the analysis, as a result of the smaller number of $\mathrm{Hp}$ and, certainly, the lower inoculum pressure for a good differentiation, it is not distinguished, at $5 \%$, from nine of the evaluated groups. Illustrating the precision, the $\mathrm{R} 2$ values, which indicate how much of the variation in losses is explained by the model, and the variation coefficients for the medium, high and low levels were, respectively, 0.978; 0.988; 0.977 and 31.2713 .75 and 50.86.

There were also clear distinctions among the other groups, which can be seen by observing the means and LSDs (Table 2), in this case with less precision than by the T test - it was calculated the DMSs, using the harmonic mean of the number of repetitions for groups.

The lowest averages were observed with Amazonian groups and groups that include materials selected for resistance (VE, OC - Wadsworth et al., 1997). And as a peculiarity, the APA series, consisting of clones APA 4 and 5 , which may in fact be a single genotype, with a very consistent lignified layer inside the pod skin, which could be a factor for insects and rodent's resistance, was the series that presented the highest proportion of IP (in the three levels of inoculum pressure - data not shown for medium and high levels).

At the medium level of infection, among the groups known as not to be associated with Scavina, stood out the group AC, formed by materials collected in Acre; group CSU, composed of the Cruzeiro do Sul and RB series, both also from Acre; group POU, of the Pound series, and series PA, both from the Peruvian Amazon; and RR, a CAB series group collected in Rondônia. Two non-Amazonian groups also stood out: OC, from the Ocumare series, and VE, from the Chuao, Choroni, PQTO and Playa Alta series, all from Venezuela.

Some clones were selected based on this data of resistance in pods and data of vegetative and cushions brooms, to form bases of the recurrent selection program initiated in this period, and many of them proved themselves as good materials per se and as parents, regarding resistance to WBD (Paim et al., 2006; Pimenta Neto, et al., 2018; Pires et al., 2012a; Pires et al., 2012b; Silva et al., 2010; Yamada et al., 2014).

The proportion of WBD infected pods was positively correlated with the total number of brooms ( $\mathrm{TB}=$ vegetative plus cushion brooms), with the number of vegetative brooms (VB) and with the number of cushion brooms (CB), in the amounts of $0.59 ; 0.51$ and 0.29 ; respectively, for all evaluated genotypes and $0.57 ; 0.47$ and 0.24 , excluding Scavinas and descendants (it were considered data of VB and CB from the Germplasm evaluation). This relation is even more evident when considering only the resistant genotypes: of 34 accessions with data on IP among the 40 selected by the lowest average of TB, only three have higher IP proportions than the collection average, so that there are very favorable prospects for gains with indirect selection.

Regarding a comparative analysis of WBD with the other of the two most important cocoa diseases in Brazil, for black pod (Phytophthora spp.) the best performances were also from wild groups or series of the Amazonian type or hybrids derived from this type, and the worsts from selections of cultivated materials, mainly of the Trinitarian-Criollo types (Pires et al., 1997). The proportion of black pod (BPD) infected pods is positively correlated with $T B$, and with the proportion of WBD Infected pods, when considering all evaluated genotypes (coefficients of 0.38 and 0.39 - significant at $0.01 \%$, respectively), and when Scavinas and descendants are excluded ( 0.32 and 0.33 , significant at $0.01 \%$ ). But the association seems smaller when considering only Trinitarians-Criollos materials $(0.17$ and 0.23 ; at the significance levels of 11.99 and $3.32 \%$ ) (it was considered data presented in Pires et al. (1997) and later germplasm evaluation data).

Again, the relations between characteristics are even more striking when considering only the extreme genotypes in terms of resistance. Of 22 accessions with data on BPD infected pods, among the 40 selected by the lowest averages of VB plus $\mathrm{CB}$, none has a higher proportion of pod loss than the germoplasm collection average. Of the 25 accessions with data on 
BPD infected pods, among the 40 selected by the lowest proportions of WBD infected pods, only one has a higher average than the general average. This, in addition to indicate the existence of favorable prospects for gains with indirect selection, also suggests the existence of common mechanisms in the resistance to the two diseases (metabolites related to pathogenicity analogous in different species of fungi have been observed for a long time and in many cases - Wolpert et al., 2002).

2- Set 2 - distinctions among accessions and accession groups for vegetative brooms

The set of accessions evaluated here was preselected, among the accessions introduced in the period, according to information that led to prospects of good performance in relation to WBD, and grafted onto adult plants to accelerate their development, in order to achieve faster evaluation. Such accessions were established in areas with high inoculum pressure, with a susceptible genotype (SIC 23) intercalated among them, who, however, did not survive in any of his positions. This has also occurred with some accessions; thus, the survival of the materials is an indicator of resistance. The loss of this pattern of susceptibility impoverishes the results, but this occurrence is compensated, in part, by the presence of the series GNV, considered as a pattern of resistance. The series GNV is derived from a selection of plants in progenies of Scavina 6,12 and EET 400 (descendant of Silécia 1) by the University of Gainesville - Florida, through screening by artificial inoculation (Wadsworth et al., 1997).

In the subset A, with 91 accessions, it was observed significant effects of removal period, block, series (described in Table 3), accessions within series, removal period $\mathrm{x}$ series, planting age $\mathrm{x}$ series, removal period $\mathrm{x}$ accession within series and trunk area at $20 \mathrm{~cm}$ from the ground, up to $2 \%$ probability. The planting age and the planting age $\mathrm{x}$ accession within the series are significant, at $2 \%$, when not adjusted by the trunk area, but the first is significant at only 5\%, when adjusted, and the second is not significant, which shows that the consideration of plant size produces some adjustment for age differences.

Using the repeated measures method (PROC GLM - REPEATED - SAS INSTITUTE, 1988), for the interpretation of the effects of removal period and interactions that include it, no significant effects were observed for removal period and removal period $\mathrm{x}$ planting age, but the effects of removal period $x$ series and removal period $\mathrm{x}$ accession within series remained significant. The significance of the interactions illustrates the difficulties in evaluating resistance and the need to contemplate a wide period of time to obtain data that adequately represent the genotypes.

The group formed by the two Moronas and the one formed by the two CABs showed averages for the number of vegetative brooms numerically inferior and statistically not different from that of GNVs (Table 3 averages obtained from the transformation of the variable by extracting its square root, to approximate the distribution from normal curve; differences among variances within the series not bigger than 7 times; LSD obtained from the complete model for the harmonic mean of the number of repetitions per group or series). The Ucayali series, supposedly collected in the same region of Scavina; $\mathrm{Gu}$, from French Guiana, and $\mathrm{CCN}$, from Ecuador, also showed averages very close to that of GNVs (without significant distinction for the contrasts), which suggests that special attention

Table 3 - Transformed means of accession groups for the number of vegetative brooms (VB), number of accessions for each group $(\mathrm{N})$, probabilities of error for the rejection of the null hypothesis of contrasts between means of each series with the GNV series (C-GNV), and Least Significant Difference for Tukey, at $5 \%$, obtained for the harmonic mean of the number of group repetitions (LSD) - subset A

\begin{tabular}{lrrrl}
\hline Group & N & VB & C-GNV & Group Origin \\
\hline Amazon & 2 & 1.554 & $<.0001$ & Peru \\
CAB & 2 & 0.869 & 0.6204 & Brazilian Amazon \\
CCN & 3 & 1.047 & 0.4943 & CCN 51, descendant \\
EB & 16 & 1.138 & 0.0422 & Ecuador-Nacional \\
EQX & 3 & 1.316 & 0.0047 & Equador \\
GNV & 11 & 0.942 & & Hybrids \\
Gu & 21 & 1.030 & 0.2205 & French Guiana \\
Huallaga & 7 & 1.444 & $<.0001$ & Peru \\
IMC & 2 & 1.122 & 0.2098 & Peru \\
LCTEEN & 3 & 1.109 & 0.2395 & Ecuador \\
Morona & 2 & 0.756 & 0.1564 & Peru \\
Na & 3 & 1.561 & $<.0001$ & Peru \\
Pound & 5 & 1.157 & 0.0293 & Peru \\
Scavina & 4 & 1.143 & 0.0484 & Peru \\
Ucayali & 7 & 1.081 & 0.0890 & Peru \\
\hline LSD Tukey & $5 \%$ & 0.400 & & \\
\hline
\end{tabular}


should be devoted to these series. IMC, from Peru and LCTEEN, from Ecuador, also did not differ from the GNV series.

The EB series, which was generated in Ecuador by a contest of broad engagement among farmers for the selection of plants of the national type resistant to WBD, showed a higher average than the GNV series, at $5 \%$ of significance, but no different at $1 \%$ (contrast). This also occurred for the Scavina and Pound series.

In assessing the differences among individual clones of subset $\mathrm{A}$, the accessions were divided into two groups, one with 47 and the other with 41 elements, according to the variances within access, so that, in each group, the largest did not exceed the smallest in 7 times (three accessions had zero brooms). Significance was observed for the effects: removal period, block, accession, removal period $\mathrm{x}$ accession, and trunk area at $20 \mathrm{~cm}$ from the ground (covariate covariance analysis), with the first group, and for these and planting age and planting age $\mathrm{x}$ accession for the second group, at $5 \%$.

The averages, estimated with the removal of interactions from the model, of the accessions with the lowest incidence of the disease are shown in Table 4, together with the general averages of the two groups and the respective LSDs, obtained from the complete model from the harmonic average for cell repetitions. It were listed only the accessions that had averages lower than that presented by the GNV series, and this list included 23 genotypes of the series Gu, EB, Morona, Huallaga, LCTEEN, Ucayali, Pound, Scavina e EQX. These results confirm the expectations about resistance for the genotypes included in this evaluation process.

For subset B, of 63 accessions, significant effects of removal period, series, accession within series, removal period $\mathrm{x}$ series, removal period $\mathrm{x}$ accession within series, and trunk area, were observed at the level of $0.01 \%$ probability. This subset analyzed with the removal period as a repeated measure and by multivariate analysis produced similar results, with a single difference: no significant effects were observed for the removal period.

The series considered presented the following averages: CAB (42 accessions) - 0.784; EQX (3 accessions) - 0.373; Gu (5 accessions) - 0.472; Huallaga (6 accessions) - 1,144; IMC (2 accessions) 1.03 and Ucayali (2 accessions) - 0.176 (averages obtained transforming the variable by extracting its square root). The LSD, for Tukey at $5 \%$ significance was 0.350 . Three other clones, each one of a different series, were not included in this analysis. So, the good performance of the $\mathrm{Gu}$ and Ucayaly series was repeated, now accompanied by the EQX group. The three representatives of this group (EQX 69, EQX 3348 and Coca 3370) come from collections in the region of the Coca River, while the EQXs of subset $\mathrm{A}$

Table 4 - Transformed means of accessions for the number of vegetative brooms (VB), general means, Least Significant Difference (LSD), for Tukey, at $5 \%$, and group related to the dimensions of variance to which each accession belongs (Group 0 $=$ variance 0 ) - Subset $\mathrm{A}$

\begin{tabular}{|c|c|c|c|}
\hline Series & Clone & Group & VB \\
\hline GU & GU 171C & 0 & 0.09 \\
\hline EB & EB Rosa Maria & 1 & 0.33 \\
\hline Morona & MO 20 & 1 & 0.36 \\
\hline $\mathrm{EB}$ & EB 0508 & 1 & 0.39 \\
\hline GNV & GNV 22 & 1 & 0.47 \\
\hline GNV & GNV 263 & 1 & 0.48 \\
\hline $\mathrm{GU}$ & GU 261C & 0 & 0.55 \\
\hline Morona & MO 81 & 1 & 0.56 \\
\hline Huallaga & Н 39 & 1 & 0.57 \\
\hline GNV & GNV 120 & 1 & 0.57 \\
\hline LCTTEEN & LCTEEN 241 & 1 & 0.58 \\
\hline Ucayali & U 32 & 0 & 0.59 \\
\hline $\mathrm{GU}$ & GU $123 \mathrm{C}$ & 1 & 0.62 \\
\hline GU & GU $123 \mathrm{C}$ & 1 & 0.62 \\
\hline GNV & GNV 27 & 1 & 0.64 \\
\hline GNV & GNV 113 & 1 & 0.65 \\
\hline $\mathrm{GU}$ & GU $221 \mathrm{H}$ & 1 & 0.66 \\
\hline GU & GU 171C & 1 & 0.67 \\
\hline GNV & GNV 63 & 1 & 0.68 \\
\hline Pound & P 2A & 1 & 0.69 \\
\hline $\mathrm{CCN}$ & CCN 51 & 1 & 0.71 \\
\hline Scavina & SCA 9 & 1 & 0.73 \\
\hline EET & EET 400 & 1 & 0.78 \\
\hline EB & EB 1010 & 1 & 0.78 \\
\hline Ucayali & U 11 & 1 & 0.78 \\
\hline EB & EB 1203 & 1 & 0.80 \\
\hline EQX & EQX 31611 & 1 & 0.80 \\
\hline EB & EB 0509 & 1 & 0.81 \\
\hline GNV & GNV 258 & 2 & 0.81 \\
\hline SCA & SCA 5 & 1 & 0.82 \\
\hline Huallaga & Н 03 & 1 & 0.82 \\
\hline Average & & 1 & 0.79 \\
\hline Average & & 2 & 1.47 \\
\hline LSD-Tukey-5\% & & 1 & 0.74 \\
\hline LSD-Tukey-5\% & & 2 & 1.06 \\
\hline
\end{tabular}


results from a prospection in the region of the San Miguel River, both in the east of Ecuador (Wadsworth et al., 1997).

For the evaluation of the differences among individual clones of subset $\mathrm{B}$, similarly to that performed for A, the accessions were divided into two groups, one with 13 and the other with 48 elements, according to the variances within accession. For these, significance was observed for the effects: removal period, accession and removal period $\mathrm{x}$ accession, with the first group (covariate trunk area non-significant), and for all with the second.

Now taking the $\mathrm{Gu}$ series as a reference, Table 5 lists the accessions that had averages lower than that presented by this series, the general averages of the two groups and the respective LSDs, obtained from the reduced model, with the harmonic average of the accession's repetitions, for the first and second groups,

Table 5 - Transformed means of accessions for the number of vegetative brooms (VB), general means, Least Significant Difference (LSD) for Tukey, at $5 \%$, and group related to the dimensions of variance to which each accession belongs (Group 0 $=$ variance 0$)$ - Subset $\mathrm{B}$

\begin{tabular}{llcc}
\hline Series & \multicolumn{1}{c}{ Clone } & Group & VB \\
\hline Scavina & SCA 19 & 1 & 0.00 \\
CAB & CAB 324 & 0 & 0.02 \\
CAB & CAB 148 & 0 & 0.04 \\
CAB & CAB 169 & 1 & 0.07 \\
LCTEEN & LCTEEN 37 & 1 & 0.07 \\
CAB & CAB 197 & 1 & 0.13 \\
Ucayali & U 10 & 1 & 0.13 \\
Coca & Coca 3370 & 1 & 0.15 \\
CAB & CAB 94 & 1 & 0.16 \\
CAB & CAB 157 & 1 & 0.20 \\
CAB & CAB 301 & 1 & 0.21 \\
CAB & CAB 191 & 1 & 0.22 \\
Ucayali & U 16 & 1 & 0.28 \\
GU & GU 221C & 1 & 0.34 \\
CAB & CAB 196 & 2 & 0.36 \\
CAB & CAB 309 & 1 & 0.42 \\
GU & GU 125C & 2 & 0.42 \\
CAB & CAB 500 & 2 & 0.45 \\
Amazon & Amazon 15 & 2 & 0.49 \\
CAB & CAB 165 & 2 & 0.54 \\
\hline Average & & 1 & 0.18 \\
Average & & 2 & 0.93 \\
LSD-Tukey-5\% & & 1 & 0.41 \\
LSD-Tukey-5\% & & 1.00 \\
\hline
\end{tabular}

respectively. Again, there is the inclusion of a large number of accessions from different series: 18 accessions from the series: CAB, Scavina, LCTEEN, Ucayali, Coca and Amazon.

Once more, some accessions were selected based on data of VB resistance, to form some of the clone trials and progeny trials that constituted the bases of the recurrent selection program that are carried off at the Cocoa Research Center in Ilhéus, Bahia, and many proved themselves as good materials regarding resistance to WBD (Pimenta Neto et al., 2018; Rodrigues et al., 2020).

In general, for VB and WBD infected pods, or for the two set of clones evaluated, a large number of genotypes of different origins were among the resistant ones, indicating the perspective of the occurrence of different resistance genes and possibilities of gain in associating these different genes. This has been confirmed in other studies (Albuquerque et al., 2010; Paim et al., 2006; Pimenta Neto et al., 2018; Pires et al., 2012a; Pires et al., 2012b; Rodrigues et al., 2020).

\section{Conclusions}

The large number of genotypes of different origins observed among the resistant ones for VB and WBD infected pods, indicate the perspective of the occurrence of different resistance genes and possibilities of gain in associating these different genes.

For WBD infected pods, the best performances were obtained by groups of Amazonian materials, notably of series collected in Acre State, Rondônia, and the Peruvian Amazon, indicating these areas as very important for prospecting for new materials. Two groups of non-Amazonian materials, from Venezuela, were also highlighted.

The average for WBD infected pods of Scavina descendants, who represent the majority of varieties indicated for commercial planting in Bahia, approaches the averages of the traditional local varieties with a high level of inoculum pressure, so that, for these varieties, high pod loss is expected in commercial planting situations with high inoculum pressure.

The proportion of WBD infected pods is positively correlated with the numbers of $\mathrm{VB}, \mathrm{CB}$ and $\mathrm{TB}$, and there are very favorable prospects for gains with indirect selection. 


\section{Literature Cited}

ALBUQUERQUE, P. S. B. et al. 2010. Novel sources of witches' broom resistance (causal agent Moniliophthora perniciosa) from natural populations of Theobroma cacao L. from the Brazilian Amazon. Euphytica (172):125-138.

BENJAMIN, C. S.; LUZ, E. D. M. N.; PIRES, J. L. 2016. Cacao families and parents selected as resistant to natural infection of Moniliophthora perniciosa. Crop Breeding and Applied Biotechnology (16):141-146.

CRUZ, C. D. Programa GENES: aplicativo computacional em genética e estatística. 1997. Viçosa, MG, UFV. 442p.

CRUZ, C. D.; CARNEIRO, P. D. S.; REGAZZI, A. J. 2014. Modelos biométricos aplicados ao melhoramento genético. Viçosa, MG, UFV. 668p.

GRAMACHO, K. P. et al. 2016. Pathogenic variability of Moniliophthora perniciosa in three agroecological zones of the cacao region of Bahia, Brazil. Crop Breeding and Applied Biotechenology (16):07-13.

LOPES, U. V. et al. 2011. Cacao breeding in Bahia, Brazil: Strategies and results. Crop Breeding and Applied Biotechnology (11):73-81.

LUZ, E. D. M. N.; SGRILLO, R. B.; SANTOS FILHO, L. P. 2005. Quantificação de perdas causadas por doenças em cacaueiro. In: Ribeiro do Valle, F.X. (Org.). Quantificação de perdas no manejo de doenças em plantas. Viçosa, MG, UFV. pp.104-121.

PAIM, V. R. L. M. et al. 2006. Sources of resistance to Crinipellis perniciosa in progenies of cacao accessions collected in the Brazilian Amazon. Scientia Agricola (63):572-578.

OLIVEIRA, M. L.; LUZ, E. D. M. N. 2012. Principais doenças do cacaueiro e seu manejo. In: Valle, R. R. (Org.). Ciência, tecnologia e manejo do cacaueiro. Brasília, DF, Ceplac. pp.187-275.
PIMENTA NETO, A. A. et al. 2018. Selection of cocoa progenies for resistance to witches' broom. Tropical Plant Pathology (43):381-388.

PIRES, J. L.; LUZ, E. D. M. N.; LOPES, U. V. 1997. Resistência em campo de clones de cacaueiro à Podridão-Parda, causada por Phytophthora spp na Bahia, Brasil. Fitopatologia Brasileira (22):375380.

PIRES, J. L. et al. 2012a. Association among sources of resistance to witches' broom disease for the increment of the level and durability of the character. Agrotrópica (Brasil) (24):27-30.

PIRES, J. L. et al. 2012b. New genes of resistance to witches' broom identified by the behavior of different clones over time In: 17th International Cocoa Research Conference, Lagos, Nigeria, 2012. Proceeding, COPAL, Lagos, Nigeria. pp.169-175.

SILVA, S. D. V. M. et al. 2010. Parent selection for cocoa resistance to witches' broom. Pesquisa Agropecuária Brasileira (45):680-685.

RODRIGUES, G. S.; PIRES, J. L.; LUZ, E. D. M. N. 2020. Association of genes from different sources of resistance to major cacao diseases. Revista Ceres (Brasil) (67):383-394.

SAS INSTITUTE INC. SAS/STAT User's Guide. Release 6.03. 1988 Cary, NC: SAS Institute Inc. $1028 \mathrm{p}$.

WADSWORTH, R. M. et al. 1997. International Cocoa Germplasm database. London, LIFFE. 1200p.

WOLPERT, T. J.; DUNKLE, L. D.; CIUFFETTI, L. M. 2002. Host-selective toxins and avirulence determinants: What's in a name. Annual Review of Phytopathology (40):251-85.

YAMADA, M. M. et al. 2014. Ocorrência de vassoura-de-bruxa em progênies de cacaueiro selecionadas pelo programa de melhoramento na Estação Experimental Joaquim Bahiana. Agrotrópica (Brasil) (26)197-202. 